\title{
Effects of temperature on uptake of aqueous metals by blue mussels Mytilus edulis from Arctic and temperate waters
}

\author{
Stephen B. Baines ${ }^{*}$, Nicholas S. Fisher, Erin L. Kinney \\ Marine Sciences Research Center, Stony Brook University, Stony Brook, New York 11794-5000, USA
}

\begin{abstract}
Arctic waters are contaminated with metals and radionuclides from diverse sources. Here we present experimental results evaluating the bioaccumulation of dissolved metals by the mussel Mytilus edulis, widely used as a food source and also as a bioindicator of coastal contamination. We used radioisotopes to determine the uptake and excretion of $\mathrm{Ag}, \mathrm{Am}, \mathrm{Cd}, \mathrm{Co}$ and $\mathrm{Zn}$ by $\mathrm{M}$. edulis collected from both Arctic and temperate waters at 2 and $12^{\circ} \mathrm{C}$. For both mussel populations, uptake rates $\left(k_{\mathrm{u}}\right)$ of $\mathrm{Cd}$, Co and $\mathrm{Zn}$ were 50 to $60 \%$ slower at $2^{\circ} \mathrm{C}$ than at $12^{\circ} \mathrm{C}$, mainly attributable to differences in mussel filtration rates at these temperatures, whereas uptake of Ag and Am was not affected by temperature. For both populations, the first-order loss constant for all metals from the slowest exchanging pool $\left(k_{\mathrm{e}}\right)$ was 20 to $50 \%$ smaller at $2^{\circ} \mathrm{C}$ than at $12^{\circ} \mathrm{C}$. As well, the loss of $\mathrm{Cd}$ and $\mathrm{Zn}$ was significantly slower in the temperate mussels than in Arctic mussels. Because temperature had similar effects on uptake and efflux, the concentration factor for all metals from water $\left(\mathrm{CF}_{\mathrm{w}}=\right.$ $k_{\mathrm{u}} / k_{\mathrm{e}}$ ) did not vary significantly between temperatures, but $\mathrm{CF}_{\mathrm{w}}$ values for $\mathrm{Cd}$ and $\mathrm{Zn}$ in temperate mussels were 15-fold and 2.6-fold higher, respectively, than in Arctic mussels. Thus, while temperature does not exert a major influence on net bioaccumulation of aqueous metal by M. edulis, Arctic mussels may accumulate dissolved $\mathrm{Cd}$ and $\mathrm{Zn}$ to a lesser degree than temperate mussels.
\end{abstract}

KEY WORDS: Contaminants $\cdot$ Kinetic modeling $\cdot$ Radionuclides $\cdot$ Bioaccumulation $\cdot$ Concentration factors

\section{INTRODUCTION}

Despite the generally pristine nature of Arctic marine ecosystems, regionally there are concerns about exposure of Arctic organisms to toxic trace metals and radionuclides. Smelting and mining can cause locally high dissolved concentrations of a wide range of potentially toxic metals, including $\mathrm{Zn}, \mathrm{Pb}, \mathrm{Cu}, \mathrm{Ni}$ and Hg (Dietz et al. 1998). Small but measurable amounts of radionuclides have been introduced into Arctic marine ecosystems from nuclear fuel reprocessing plants in Western Europe via currents, while larger amounts have entered from fallout from nuclear weapons testing and the Chernobyl accident, and from disposal and accidental losses of radioactive materials directly into Arctic waters (Strand 1998). Since many of these toxic metals and radionuclides are very particlereactive, they may be accumulated efficiently from solution by phytoplankton (Fisher 1986) and then passed up the food chain. While concentrations of these substances are rarely elevated above background levels, local dissolved metal or radionuclide concentrations near waste-disposal or mine sites may be so high that absorption of aqueous metal directly from solution may also be an important source of contaminant loads in invertebrate tissues. This could potentially lead to local toxic effects either in the accumulating organisms, or the organisms that feed on them, including humans (Templeton et al. 1997, Hansen 1998).

The potential for bioaccumulation of toxic metals and radionuclides by marine invertebrates can be assessed using biokinetic models (Fisher et al. 1996, Wang et al. 1996, Reinfelder et al. 1998). These models assume that animals can accumulate metal directly from the dissolved phase as well as from dietary 
sources, with the relative importance of each pathway varying appreciably among metals (Wang \& Fisher 1999). To evaluate the potential accumulation of metals in animals, it is necessary to measure the bioavailability of metals from each uptake pathway. Once the kinetic parameters are quantified, model predictions of metal concentrations in animal tissue can be made on a site-specific basis. When this has been done for marine and freshwater invertebrates and for fishes, model predictions have closely matched independent field measurements (Wang et al. 1996, Fisher et al. 2000, Roditi et al. 2000, Baines et al. 2002, Griscom \& Fisher 2002), suggesting that (1) we can account for the key processes governing metal concentrations in biota, and (2) the experimentally determined kinetic parameters are generally applicable to field conditions.

It is not known to what extent the extensive data on aqueous metal uptake and retention by Mytilus edulis can be applied to polar regions. Previous studies have measured the bioaccumulation of dissolved metals in temperate populations of $M$. edulis maintained at temperatures of $15^{\circ} \mathrm{C}$ (Wang et al. 1996). However, no studies have determined the aqueous metal uptake rates in this mussel at the cold temperatures that normally prevail in polar waters, nor have Arctic and temperate populations been compared in this regard. The uptake and retention of dissolved metal by invertebrates from temperate zones is affected by temperature in significant but variable ways (Hutchins et al. 1996, 1998). Furthermore, Arctic and temperate organisms may exhibit distinct adaptations to their environments. Where these adaptations involve processes such as filtration that are involved in uptake of metal, or processes such as respiration which may influence loss of metal, differences in metal bioaccumulation by Arctic and temperate organisms may also arise. Such differences need to be assessed before we can confidently apply biokinetic parameters determined for temperate populations to the Arctic.

In this study, we employed radiotracer methodology to determine the uptake rate, the first-order efflux constant, and the partitioning of metals among pools of different turnover rates and between soft tissues and shell of the common blue mussel Mytilus edulis. This species is cosmopolitan and widely used as a bioindicator of coastal contamination (Phillips 1980), and as a food source for indigenous human populations in the Arctic and elsewhere. The metals we have chosen are representative of contaminant metals $(\mathrm{Ag}, \mathrm{Cd}, \mathrm{Zn})$ or anthropogenic radionuclides $\left({ }^{110 \mathrm{~m}} \mathrm{Ag},{ }^{241} \mathrm{Am},{ }^{60} \mathrm{Co}\right.$, ${ }^{65} \mathrm{Zn}$ ) measured in Arctic waters and organisms (Dietz et al. 1998, Strand 1998, Fisher et al. 1999). They also range in chemical and biological behavior, with varying affinities for sulfur and oxygen ligands, biological function, and degrees of toxicity (Nieboer \& Richard- son 1980). We compared the bioaccumulation of these metals from the aqueous phase by mussels obtained from Arctic and temperate waters at 2 temperatures that are near the extremes experienced in Arctic environments. The data we obtained on bioaccumulation of metal from solution complement similar data on the bioavailability of dietary metal to Arctic and temperate M. edulis (Baines et al. 2005).

\section{MATERIALS AND METHODS}

Mussels Mytilus edulis from the Arctic were collected (courtesy of Dr. Lars Føyn) from the north coast of Norway during the first week of October 2000 $\left(69^{\circ} \mathrm{N}, 38^{\circ} \mathrm{S}\right.$, water temperature about $\left.6^{\circ} \mathrm{C}\right)$ and transported to Tromsø, Norway. Molecular studies have shown that $M$. edulis is the only member of the genus from this area (Riginos et al. 2002). Precautions were taken to ensure little stress to the mussels in transit (Baines et al. 2005). Total transit time from northern Norway to New York was $<2 \mathrm{~d}$ and no mussel mortality occurred during transit. Mussels representative of temperate systems were collected on 15 March (prior to the spawning period) and 3 November 2003 (after spawning) from Long Island Sound near Old Field, New York. This site is located about $75 \mathrm{~km}$ east of New York City and is relatively unimpacted by metal contamination. All mussels were kept in $0.2 \mu \mathrm{m}$ filtered Atlantic surface seawater collected $10 \mathrm{~km}$ south of Southampton, New York (designated SHSW), and maintained on a diet of the coastal diatom Thalassiosira pseudonana. Arctic mussels were maintained at 2 to $8^{\circ} \mathrm{C}$ and temperate mussels at 10 to $14^{\circ} \mathrm{C}$ until the beginning of the experiments. Mussels were 2 to $2.5 \mathrm{~cm}$ in shell length, with soft-tissue dry weights of 70 to $240 \mathrm{mg}$.

The uptake of metals was determined using gammaemitting radioisotopes for each metal. This approach enables working with low, environmentally realistic concentrations of metals in most cases, and has the further advantage of non-destructive analysis which permits the analysis of metal uptake and loss in the same individual organism over time, thereby greatly reducing the biological variability among samples (Fisher 2002). Experiments generally followed protocols described in detail elsewhere (Wang et al. 1996). For the radiolabeling phase of the experiment, $500 \mathrm{ml}$ of SHSW was added to acid-washed 11 polyethylene beakers. To these beakers, microliter additions of acidic stock solutions of radioisotopes were added; either ${ }^{109} \mathrm{Cd}$ dissolved in $0.1 \mathrm{~N} \mathrm{HCl}$ and ${ }^{65} \mathrm{Zn}$ in $0.5 \mathrm{~N}$ $\mathrm{HCl}$, or ${ }^{241} \mathrm{Am}$ in $3 \mathrm{~N} \mathrm{HNO}_{3},{ }^{110 \mathrm{~m}} \mathrm{Ag}$ in $1 \mathrm{~N} \mathrm{HCl},{ }^{57} \mathrm{Co}$ in $0.1 \mathrm{~N} \mathrm{HCl}$ were added. Final metal concentrations attributable to radioisotope additions were in the low 
$\mathrm{nM}$ range for $\mathrm{Ag}, \mathrm{Am}$, and $\mathrm{Zn}$ and the low $\mathrm{pM}$ range for $\mathrm{Cd}$ and $\mathrm{Co}$, generally corresponding to radioactivities of hundreds of $\mathrm{Bq} \mathrm{ml} \mathrm{ml}^{-1}$. Prior to addition of radioisotopes, sufficient $0.1 \mathrm{~N}$ SupraPur $\mathrm{NaOH}$ was added to ensure that the solutions would have a $\mathrm{pH}$ of 8.0 after addition of the isotopes. The radioactive solutions were allowed to equilibrate for at least $12 \mathrm{~h}$ prior to addition of mussels. They were then placed in an incubator maintained at either 2 or $12^{\circ} \mathrm{C}$. Throughout the experiment, temperature was monitored using a submersible temperature logger (Hobo, Onset Corporation). Temperatures remained within $2^{\circ} \mathrm{C}$ of the experimental temperature throughout the experiments.

Prior to radiolabeling, mussels were starved for $12 \mathrm{~h}$ to reduce the production of feces during exposure to dissolved metal. These mussels were cleaned of epibiota and placed centrally in the beakers containing the radioactive seawater. Mussels were allowed to filter the water for $12 \mathrm{~h}$, after which they were rinsed with chilled SHSW and placed into $60 \mathrm{ml}$ plastic vials containing seawater chilled to the experimental temperature. The mussels were analyzed for gamma emissions while in these vials. We also assessed radiolabel uptake over time by temperate mussels to determine if uptake of aqueous metal accumulated at a constant rate over the duration of the exposure period. Uptake of radiolabel by entire mussels was assayed every $2 \mathrm{~h}$ for $12 \mathrm{~h}$ in these experiments. In addition, we conducted experiments to determine if the exposure period affected the distribution of metal between soft tissues and shell after 3,6 and $9 \mathrm{~h}$ of exposure to dissolved metal. These experiments had to be conducted separately from the whole-mussel uptake experiments because of the destructive nature of the sampling at each time point. They were only conducted at $12^{\circ} \mathrm{C}$ using temperate mussels collected in mid-November.

After exposure to the radioactive solution, 3 to 4 of the mussels were frozen in liquid nitrogen and placed in a $-4^{\circ} \mathrm{C}$ freezer for later dissection and determination of tissue distribution (shell vs. soft parts). These data were used to correct the total radiolabel uptake for uptake into soft tissues. The remaining mussels were placed in depuration chambers. Mussels were maintained for up to $3 \mathrm{wk}$ in these chambers and their retention of the various radioisotopes monitored. The depuration chambers followed the design of Baines et al. (2005), that was in turn a modification of a design used by Wang et al. (1995). Basically, the system consisted of a series of chambers that contained the mussels and kept them separated from their feces to minimize recycling of dissolved label via the particulate pathway. Water was continuously circulated between the chambers and a large well-mixed and aerated (15 l) reservoir of seawater. Mussels were fed by pumping algal cells into the reservoir at a fixed rate using a peri- staltic pump. This suspension was placed into the incubator with the depuration chamber and continuously pumped into the reservoir at a rate of $8.2 \mathrm{ml} \mathrm{h}^{-1}$. There were 9 to 12 mussels in each depuration chamber, and the supply of food to each mussel in all experiments was $1.7 \mathrm{mg}$ dry wt $\mathrm{d}^{-1}$. As algal concentrations remained relatively unchanged over the course of the experiments, this rate approximates the feeding rate per mussel. Water in these chambers was also monitored for dissolved radioactivity. The chamber water was replaced with new SHSW after the first day of depuration and periodically thereafter. This procedure kept dissolved concentrations of radioisotopes low and prevented re-uptake of dissolved metal by the mussels. Inspection of gamma spectra indicated that cross-contamination between the ${ }^{108} \mathrm{Cd}^{65} \mathrm{Zn}$-labeled mussels and the ${ }^{110 \mathrm{~m}} \mathrm{Ag}_{-}{ }^{241} \mathrm{Am}-{ }^{57} \mathrm{Co}-$ labeled mussels (which used a common depuration reservoir) was insignificant.

Periodically after the beginning of depuration, the mussels in the depuration chambers were assayed for radioactivity. To determine how the distribution of radiolabel between shell and soft tissue differed after depuration among metals at different temperatures, we also conducted a relatively short-term experiment with temperate mussels in which we sacrificed all individuals after $8 d$, i.e. after absolute loss rates had measurably slowed for all the elements and the distributions had stabilized. The mussels used in this experiment were collected in mid-March. We also conducted a separate experiment at $12^{\circ} \mathrm{C}$ using the temperate mussels collected in November to determine how the time series of depuration from soft tissues and shell differed among the metals. In this experiment, mussels were harvested at least 3 times: at $0.5 \mathrm{~d}$, at 3 to $5 \mathrm{~d}$ after the initial period of rapid efflux of radiolabel, and at the end of the depuration experiment. Mussels were harvested by removing them from the depuration chamber at the allotted time and freezing them immediately for later dissection.

For gamma analysis a counting vial containing a mussel was placed into a deep-well NaI(Tl) detector (Canberra) to measure gamma emissions while the others were maintained at fixed temperature in the incubators. ${ }^{109} \mathrm{Cd}$ was determined by measuring the $\mathrm{x}$-ray emissions of its short-lived daughter product $\left({ }^{109} \mathrm{Ag}\left[t_{1 / 2}=40 \mathrm{~s}\right]\right)$ at 22 to $26 \mathrm{keV}$, while gamma emissions of ${ }^{241} \mathrm{Am},{ }^{57} \mathrm{Co}$, and ${ }^{65} \mathrm{Zn}$ were assayed at 60, 122 and $1115 \mathrm{keV}$, respectively. Gamma emissions of ${ }^{110 \mathrm{~m}} \mathrm{Ag}$ were assayed at 657 and $884 \mathrm{keV}$. Background was subtracted and counting times were adjusted to be as short as possible for live mussels to keep temperature change to a minimum while achieving a relative standard deviation of $<10 \%$. After counting, the mussels and the contents of the counting chambers were transferred to beakers within the depuration 
chamber and the supply of algal food to the chamber reservoir was begun.

Prior to exposure of mussels to dissolved metals, the filtration rates of each individual were measured according the methods of Baines et al. (2005). Basically, the maximal rate at which mussels removed the diatom Thalassiosira pseudonana from $200 \mathrm{ml}$ volumes of water was measured by tracking changes in either in vivo fluorescence (measured using a Turner designs Model 10AU fluorometer, Turner Designs), or cell number (measured with a Multisizer II Coulter Counter system). Comparisons indicated that these methods yielded comparable results over the short time frames $(<1 \mathrm{~h})$ of the feeding experiments. Filtration rates were estimated by regressing the natural logarithm of the in vivo fluorescence vs. time over periods of linear decline and multiplying the resulting slope by $200 \mathrm{ml}$. These filtration rates were used to determine metal absorption efficiency in the mussels from the water pumped across the gills.

The fraction of radiolabel found in the soft tissues of the mussels sacrificed immediately after the radiolabeling phase was multiplied by the total radioactivity in the organism to estimate uptake into soft tissues. The radioactivity associated with the soft tissues of the organism was then expressed as a fraction of the initial dissolved radioactivity $\left(f_{\mathrm{u}}\right)$. The uptake rate, $k_{\mathrm{u}}$, of metal from solution (l individual ${ }^{-1} \mathrm{~h}^{-1}$ ) was estimated as $-\ln \left(1-f_{\mathrm{u}}\right)$. This uptake rate was divided by the filtration rate to obtain the absorption efficiency (AbE). The first-order exponential loss constants and sizes of different radiolabel pools, each of which is assumed to exchange directly with the aqueous environment, were estimated by regressing the natural logarithm of radioactivity in a mussel against time for each mussel. We chose between 2 or 3 compartment models based on $\mathrm{r}^{2}$ values for the whole model (adjusted for the numbers of parameters and observations) and p-values for both the entire model and the individual parameter estimates. All depurations within a treatment were modeled using the same equation. All models were separately fit to data from each mussel using an iterative Marquardt-Levenberg search algorithm in SigmaPlot 7.1 (SPSS package). Standard errors and means for each treatment were based on the individual parameter estimates for each experimental mussel within a treatment.

In an attempt to estimate the combined influence of patterns in uptake and efflux on accumulation of metal in soft tissues from solution, for each metal we also calculated a concentration factor from water, $\mathrm{CF}_{\mathrm{w}}$, described by Fisher \& Reinfelder (1995). This value was calculated according to:

$$
\mathrm{CF}_{\mathrm{w}}=k_{\mathrm{u}} / k_{\mathrm{e}}
$$

The value of $k_{\mathrm{u}}$ considers only metal absorbed into the slowest exchanging pool of metal in the soft tissues (determined through dissections); values were calculated by multiplying the rate constant for uptake in soft tissues by the proportion of label in the slowest exchanging pool, as determined from the depuration curves. This calculation assumes that the radiolabel in the slowest exchanging compartment accumulates at a constant rate over the exposure period, i.e. the slowest exchanging compartment does not reach isotopic equilibrium with the aqueous environment. As long as the radiolabel is accumulated directly from the aqueous phase, it is unlikely that the slowest exchanging compartment approached isotopic equilibrium during exposure, since the turnover of metal from the slowest exchanging compartment is generally much too slow $\left(<10 \% \mathrm{~d}^{-1}\right.$, Wang et al. 1996). It is possible, however, that aqueous radiolabel must first pass through another sizable compartment with faster kinetics before entering the slowest compartment. In this case, our method may underestimate the real $k_{\mathrm{u}}$ because the flux of radiolabel into the slowest exchanging compartment depends on the degree to which the other compartment is fully radiolabeled. However, based on simulations which employed observed efflux constants, the faster exchanging compartment had to reach equilibrium within $6 \mathrm{~h}$ of exposure to produce the distributions of radiolabel among compartments that we observed after exposure. Moreover, these simulations indicated that any bias in our estimates was always $<35 \%$, and usually $<20 \%$.

The $\mathrm{CF}_{\mathrm{w}}$ has units of $\mathrm{l} \mathrm{g}^{-1}$ (dry wt) and represents a steady-state estimate of the efficiency at which mussels concentrate dissolved metal from solution. It is analogous to the trophic accumulation factor, TAF, (equivalent to the $\mathrm{CF}_{\mathrm{f}}$ of Fisher \& Reinfelder 1995) used by Baines et al. (2005) to estimate efficiency of metal accumulation from food. The relative standard errors of the $\mathrm{CF}_{\mathrm{w}} \mathrm{s}$ were calculated by adding the relative variances of the estimated parameters used in the calculation and taking the square root.

Analysis of the effect of geographic source of the population and temperature were determined using simple ANOVA in JMP (Version 3.21, SAS Institute). The categories for geographic origin were Arctic and temperate, and for temperature 2 and $12^{\circ} \mathrm{C}$. Interaction effects were also included in the statistical models. Significance of effects was tested using an F-test that employed Type II sums of squares, which are not sensitive to the order by which variables enter the model. The uptake rate constant and absorption efficiency were logarithmically transformed to normalize the data and to eliminate heteroscedasticity. All p-values for hypothesis tests are reported here. A critical threshold p-value of 0.01 was used to assign statistical signif- 


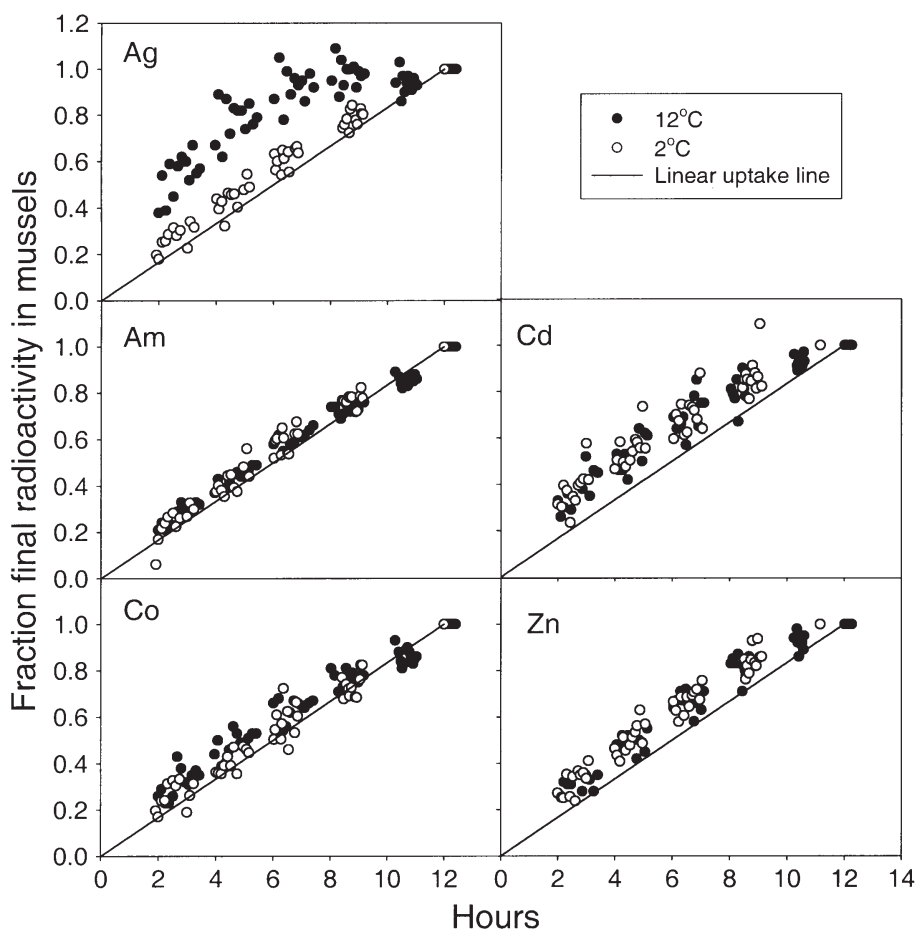

Fig. 1. Mytilus edulis. Uptake of 5 metals from the dissolved phase into temperate mussels at 2 and $12^{\circ} \mathrm{C}$ during $12 \mathrm{~h}$ exposure period. Data consist of time series for 12 different individuals and are compared with idealized linear uptake

Table 1. Mytilus edulis. Uptake rate constants $\left(k_{\mathrm{u}}\right)$ and absorption efficiencies (AbE) for metals at 2 temperatures for $12 \mathrm{~h}$ uptake experiments. $\mathrm{n}$ : number of individual mussels assayed

\begin{tabular}{|c|c|c|c|c|c|c|c|}
\hline \multirow[t]{2}{*}{ Metal } & \multirow{2}{*}{$\begin{array}{c}T \\
\left({ }^{\circ} \mathrm{C}\right)\end{array}$} & \multirow[t]{2}{*}{ Source } & \multirow[t]{2}{*}{$\mathrm{n}$} & \multicolumn{2}{|c|}{$k_{\mathrm{u}}\left(\mathrm{l} \mathrm{g}^{-1} \mathrm{~d}^{-1}\right)$} & \multicolumn{2}{|c|}{ AbE (\%) } \\
\hline & & & & Mean & SE & Mean & SE \\
\hline \multirow[t]{4}{*}{$\mathrm{Ag}$} & \multirow[t]{2}{*}{2} & Arctic & 10 & 0.63 & 0.024 & 0.39 & 0.014 \\
\hline & & Temperate & 5 & 0.86 & 0.143 & 0.48 & 0.096 \\
\hline & \multirow[t]{2}{*}{12} & Arctic & 10 & 0.52 & 0.010 & 0.24 & 0.004 \\
\hline & & Temperate & 5 & 1.44 & 0.209 & 0.35 & 0.054 \\
\hline \multirow[t]{4}{*}{$\mathrm{Am}$} & \multirow[t]{2}{*}{2} & Arctic & 10 & 0.25 & 0.036 & 0.16 & 0.021 \\
\hline & & Temperate & 5 & 0.17 & 0.011 & 0.17 & 0.015 \\
\hline & \multirow[t]{2}{*}{12} & Arctic & 10 & 0.23 & 0.011 & 0.11 & 0.005 \\
\hline & & Temperate & 5 & 0.40 & 0.047 & 0.17 & 0.014 \\
\hline \multirow[t]{4}{*}{$\mathrm{Cd}$} & \multirow[t]{2}{*}{2} & Arctic & 10 & 0.12 & 0.008 & 0.08 & 0.004 \\
\hline & & Temperate & 5 & 0.11 & 0.017 & 0.08 & 0.014 \\
\hline & \multirow[t]{2}{*}{12} & Arctic & 10 & 0.17 & 0.008 & 0.08 & 0.003 \\
\hline & & Temperate & 5 & 0.38 & 0.038 & 0.12 & 0.008 \\
\hline \multirow[t]{4}{*}{$\mathrm{Co}$} & \multirow[t]{2}{*}{2} & Arctic & 10 & 0.08 & 0.005 & 0.05 & 0.003 \\
\hline & & Temperate & 5 & 0.07 & 0.009 & 0.06 & 0.007 \\
\hline & \multirow[t]{2}{*}{12} & Arctic & 10 & 0.16 & 0.008 & 0.07 & 0.004 \\
\hline & & Temperate & 5 & 0.24 & 0.028 & 0.08 & 0.006 \\
\hline \multirow[t]{4}{*}{$\mathrm{Zn}$} & \multirow[t]{2}{*}{2} & Arctic & 10 & 0.46 & 0.050 & 0.28 & 0.028 \\
\hline & & Temperate & 5 & 0.26 & 0.037 & 0.18 & 0.028 \\
\hline & \multirow[t]{2}{*}{12} & Arctic & 10 & 0.58 & 0.041 & 0.27 & 0.016 \\
\hline & & Temperate & 5 & 1.08 & 0.148 & 0.33 & 0.025 \\
\hline
\end{tabular}

icance. However, in the following results and discussion we rarely discuss specific hypothesis tests, choosing instead to focus on whether particular treatments generally tend to cause detectable responses of consistent magnitude and direction in response variables.

\section{RESULTS}

Less than $20 \%$ of metal was absorbed from solution by the mussels over the exposure period in all experiments. Uptake by the mussels was generally linear over a $12 \mathrm{~h}$ exposure period, as shown for temperate mussels in Fig. 1, although the uptake of ${ }^{110 \mathrm{~m}} \mathrm{Ag}$ at $12^{\circ} \mathrm{C}$ slowed appreciably toward the end of the exposure period. Thus, the initial uptake rate for Ag determined from the first $2 \mathrm{~h}$ of exposure was $2.4(\sigma=0.4)$ times higher than the average for the entire $12 \mathrm{~h}$ period. For both the Arctic and temperate mussels, the uptake rate constants were largest for $\mathrm{Ag}$ and $\mathrm{Zn}$ and lowest for $\mathrm{Cd}$ and $\mathrm{Co}$, with Am being taken up at an intermediate rate (Table 1). The ANOVA of all the data indicated that these differences were highly significant, accounting for $61 \%$ of the total variance (Table 2 ). The ANOVA also revealed a significant effect of temperature on the uptake rate constant (accounting for $13 \%$ of the variance), with uptake at $2^{\circ} \mathrm{C}$ being on average $48 \%$ of that at $12^{\circ} \mathrm{C}$. Significant interaction effects indicate that the effect of temperature differed among elements and between the Arctic and temperate mussels. ANOVAs run separately on each of the metals revealed that only for $\mathrm{Cd}, \mathrm{Co}$ and $\mathrm{Zn}$ was the effect of temperature on the uptake rate constant significant, with the uptake rates at $2^{\circ} \mathrm{C}$ being 50 to $60 \%$ less than at $12^{\circ} \mathrm{C}$ (Table 3). Population source was a statistically significant determinant of the uptake rate constant, but only accounted for $2 \%$ of the variance (Table 2). Ag showed a consistent effect of population source on uptake, with the constant being $48 \%$ less in Arctic than in temperate mussels; for $\mathrm{Cd}$, the effect of population source depended upon temperature (Table 3).

Measured filtration rates for the temperate mussels were 721 and $1250 \mathrm{ml} \mathrm{h}^{-1}$ at 2 and $12^{\circ} \mathrm{C}$, respectively, while the same values for Arctic mussels were 653 and $976 \mathrm{ml} \mathrm{h}^{-1}$. Normalizing uptake to filtration rate to determine absorption efficiency removed much of the influence of temperature and population source on uptake (Tables $2 \& 3$ ). Differences among the metals were the main factor explaining variability in absorption efficiency, 
Table 2. Mytilus edulis. ANOVA results for all data on uptake rate constant $k_{\mathrm{u}}$ and absorption efficiency (AbE). Effects are metal, source (for geographic origin of mussels), temperature $T$ (for experimental temperature) and interactions between these variables. The $\mathrm{r}^{2}$ values are for the model and are adjusted for number of parameters and degrees of freedom. Bold indicates effects significant at $\mathrm{p}<0.01$

\begin{tabular}{|c|c|c|c|c|c|c|c|c|c|}
\hline \multirow[t]{2}{*}{ Effect } & \multirow[t]{2}{*}{ df } & \multicolumn{4}{|c|}{$-k_{\mathrm{u}}\left(\mathrm{l} \mathrm{g}^{-1} \mathrm{~d}^{-1}\right)$} & \multirow[b]{2}{*}{$\mathrm{r}^{2}$} & \multirow{2}{*}{$\overline{\mathrm{SS}}^{\mathrm{A}}$} & \multirow{2}{*}{$\begin{array}{l}F(\%) \\
F \text {-ratio }\end{array}$} & \multirow[b]{2}{*}{ p-values } \\
\hline & & $r^{2}$ & SS & F-ratio & $\mathrm{p}$-values & & & & \\
\hline Total & 129 & 0.87 & 19.58 & 51.3 & $<0.0001$ & 0.84 & 14.73 & 43.29 & $<0.0001$ \\
\hline Metal & 4 & 0.61 & 12.03 & 169.66 & $<0.0001$ & 0.68 & 9.98 & 161.29 & $<0.0001$ \\
\hline Source & 1 & 0.02 & 0.44 & 25.04 & $<0.0001$ & 0.01 & 0.18 & 11.84 & 0.0008 \\
\hline Metal $\times$ Source & 4 & 0.01 & 0.24 & 3.39 & 0.01 & 0.01 & 0.14 & 2.34 & 0.058 \\
\hline$T$ & 1 & 0.13 & 2.62 & 147.62 & $<0.0001$ & 0 & 0.05 & 3.02 & 0.0847 \\
\hline Metal $\times T$ & 4 & 0.03 & 0.54 & 7.62 & $<0.0001$ & 0.04 & 0.55 & 8.93 & $<0.0001$ \\
\hline$T \times$ Source & 1 & 0.05 & 0.97 & 54.82 & $<0.0001$ & 0.01 & 0.13 & 8.26 & 0.0047 \\
\hline Metal $\times T \times$ Source & 4 & 0 & 0.09 & 1.31 & 0.27 & 0.01 & 0.1 & 1.64 & 0.17 \\
\hline
\end{tabular}

Table 3. Mytilus edulis. Results of metal-specific ANOVAs on rate constants for uptake from dissolved phase $\left(k_{\mathrm{u}}\right)$ and absorption efficiencies (AbE). The 2 levels for source-population effect were Arctic and temperate, and the 2 levels for temperature effect were 2 and $12^{\circ} \mathrm{C}$. Effect size for geographic origin calculated as percentage difference according to [(Arctic $\mathrm{AbE}) /($ temperate $\mathrm{AbE})-1] \times 100$, and effect size for experimental temperature as $\left[\left(2^{\circ} \mathrm{C} \mathrm{AbE}\right) /\left(12^{\circ} \mathrm{C} \mathrm{AbE}\right)-1\right] \times 100 . \mathrm{Model} \mathrm{r}^{2}$ values adjusted for number of parameters and observations and presented as percentages; $\mathrm{r}^{2}$ values and $\mathrm{p}$-values for 'whole model' include all terms. Partial $\mathrm{r}^{2}$ values: percentage of total sums of squares accounted for by Type II sums of squares associated with effect variable (see 'Materials and methods'). Bold: model and effect values associated with p-values $<0.01$

\begin{tabular}{|c|c|c|c|c|c|c|c|c|c|c|}
\hline \multirow[t]{2}{*}{ Element } & \multicolumn{2}{|c|}{ Whole model } & \multicolumn{3}{|c|}{ — Population source $\_$} & \multicolumn{3}{|c|}{ - Temperature } & \multicolumn{2}{|c|}{ Interaction } \\
\hline & $\mathrm{r}^{2}$ & $\mathrm{p}$ & Effect & Partial & $\mathrm{p}$ & Effect & Partial & $\mathrm{p}$ & Partial & $\mathrm{p}$ \\
\hline \multicolumn{11}{|c|}{ Uptake rate constant } \\
\hline $\mathrm{Ag}$ & 68.4 & $<0.0001$ & -46 & 53.4 & $<0.0001$ & -16 & 4.3 & 0.058 & 17.8 & 0.0004 \\
\hline $\mathrm{Am}$ & 17.9 & 0.044 & -15 & 2.4 & 0.36 & -36 & 18.7 & 0.016 & 13.0 & 0.042 \\
\hline $\mathrm{Cd}$ & 78.1 & $<0.0001$ & -28 & 11.4 & $<0.0001$ & -55 & 63.5 & $<0.0001$ & 23.6 & $<0.0001$ \\
\hline $\mathrm{Co}$ & 81.3 & $<0.0001$ & -17 & 2.9 & 0.043 & -62 & 79.0 & $<0.0001$ & 3.5 & 0.027 \\
\hline $\mathrm{Zn}$ & 59.6 & $<0.0001$ & -4 & 0.1 & 0.77 & -58 & 57.2 & $<0.0001$ & 24.2 & 0.0003 \\
\hline \multicolumn{11}{|c|}{ Absorption efficiency } \\
\hline $\mathrm{Ag}$ & 53.4 & $<0.0001$ & -20 & 11.1 & 0.014 & 48 & 34.2 & $<0.0001$ & 2.0 & 0.27 \\
\hline Am & 8.2 & 0.16 & -29 & 13.0 & 0.053 & 13 & 1.6 & 0.48 & 1.5 & 0.5 \\
\hline $\mathrm{Cd}$ & 37.7 & 0.0015 & -19 & 19.1 & 0.0062 & -21 & 19.0 & 0.0063 & 19.1 & 0.0062 \\
\hline $\mathrm{Co}$ & 57.7 & $<0.0001$ & -18 & 9.9 & 0.015 & -33 & 41.9 & $<0.0001$ & 0.7 & 0.48 \\
\hline $\mathrm{Zn}$ & 21.6 & 0.025 & 12 & 2.5 & 0.35 & -27 & 17.7 & 0.017 & 18.5 & 0.014 \\
\hline
\end{tabular}

accounting for $68 \%$ of the total variance. Whereas temperature could not explain a significant fraction of the variability in the absorption efficiency, the interaction term with population source was significant. Although population source had a significant effect on its own, it explained only $1 \%$ of the variability in the absorption efficiency. The lack of strong effects of population and temperature on absorption efficiency reflects the fact that filtration rates and uptake rates varied similarly with temperature and population source. The element-specific ANOVAs do reveal some significant effects of temperature and population source on the absorption efficiency. These differences were smaller, but generally in the same direction as for the uptake rate constants. The exception is Ag, for which the absorption efficiency was $50 \%$ higher at 2 than at $12^{\circ} \mathrm{C}$.

Loss of metal from the mussels during depuration was generally exponential, and models representing exponential loss from 2 pools with different loss con- stants generally fit the data best (Figs. $2 \& 3$, Table 4). The exceptions were Ag in the temperate mussels at $12^{\circ} \mathrm{C}$, which required a 3-pool model, and Am in the Arctic mussels at $2{ }^{\circ} \mathrm{C}$, for which only a single pool was required (Table 4). Loss rates were generally $>100 \% \mathrm{~d}^{-1}$ for the rapidly exchanging pools, and $<10 \% \mathrm{~d}^{-1}$ for the slowly exchanging pools. The pool with the slowest efflux rate always accounted for 60 to $100 \%$ of the absorbed Am, Cd, Co and Zn. The exception was Ag in the temperate mussels, for which the slowest turnover pool only accounted for 23 to $48 \%$ of the absorbed metal. The unusually small size of the slowest exchanging pool in this experiment was largely responsible for the significant effect of population source in the ANOVA with all metals (Table 5). Significant differences also existed between the Arctic and temperate mussels for $\mathrm{Am}, \mathrm{Cd}$ and $\mathrm{Co}$, but these differences were of mixed direction and were all modest in size $(<25 \%)$. Temperature had a significant but modest 


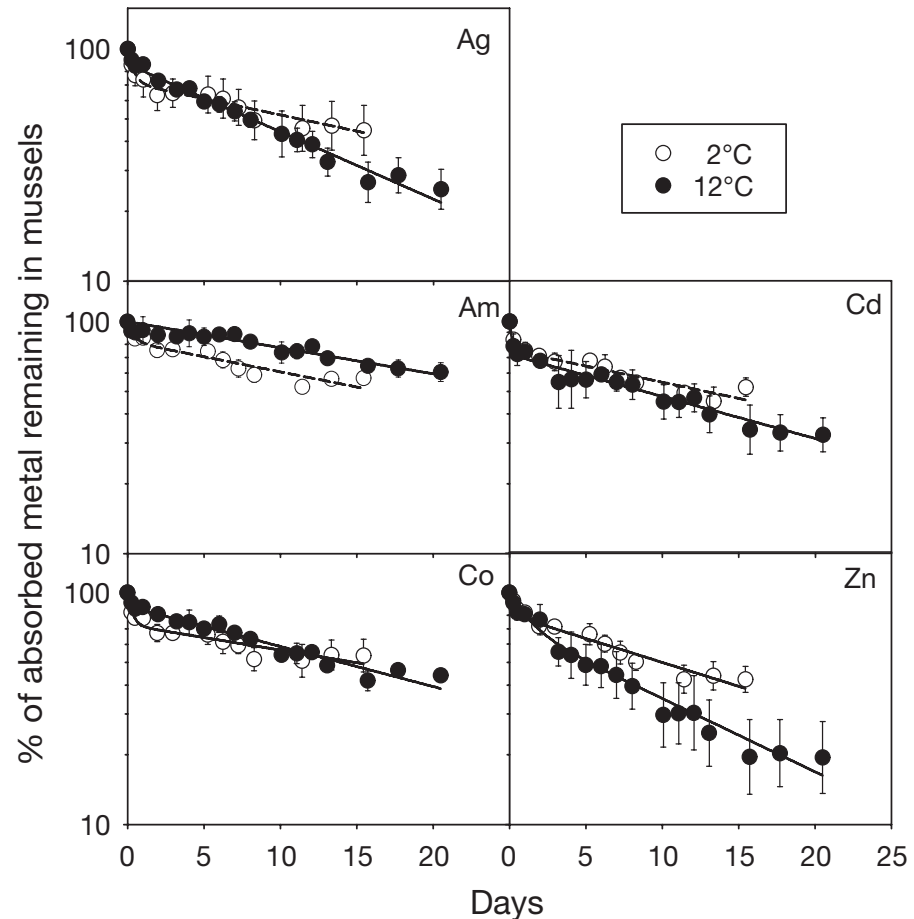

Fig. 2. Mytilus edulis. Time series of metal loss from Arctic mussels at 2 and $12^{\circ} \mathrm{C}$. Data points are means of 4 to 6 replicates $\pm \mathrm{SD}$; regression lines through data are double exponential loss curves fitted to means

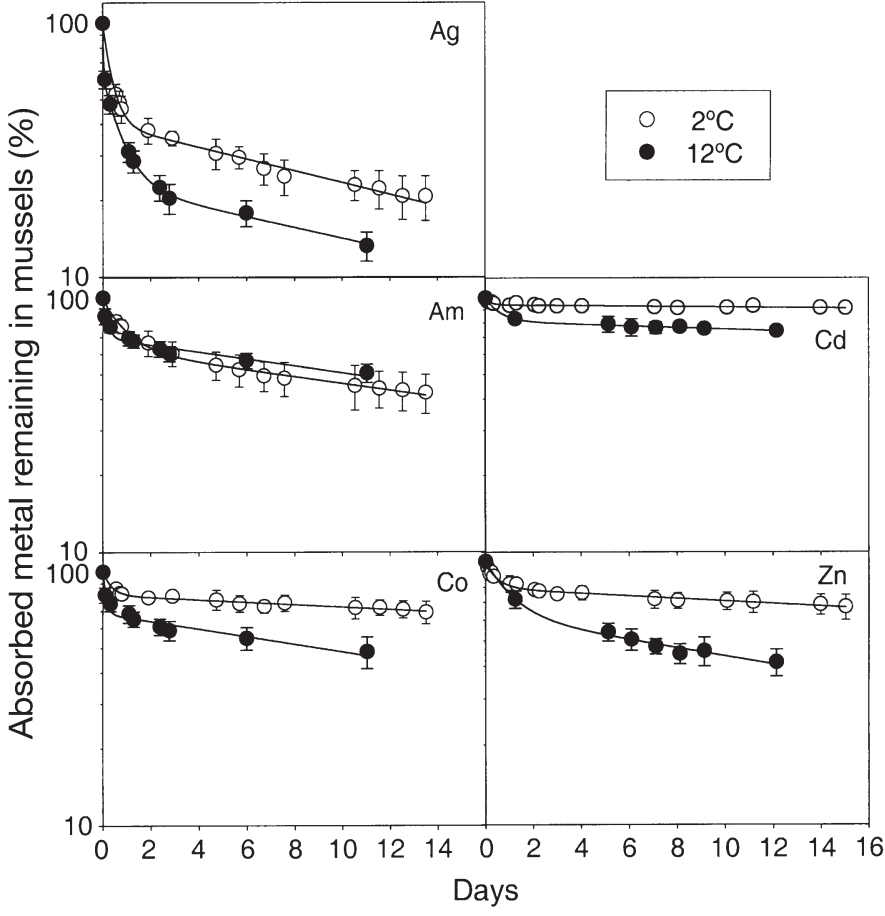

Fig. 3. Mytilus edulis. Time series of metal loss from temperate mussels at 2 and $12^{\circ} \mathrm{C}$. Data points are means of 3 to 6 replicates $\pm \mathrm{SD}$. Regression lines through data are double exponential loss curves fitted to means

Table 4. Mytilus edulis. Parameters from depuration experiments after exposure to dissolved metals. Pool A: slowest exchanging pool; Pool B: rapidly exchanging pool; Pool C: most rapidly exchanging pool for Ag in temperate mussels at $12^{\circ} \mathrm{C}$. $k_{\mathrm{e}}$ : uptake rate constant

\begin{tabular}{|c|c|c|c|c|c|c|c|c|c|c|c|c|c|c|c|}
\hline \multirow[t]{3}{*}{ Metal } & \multirow{3}{*}{$\begin{array}{c}T \\
\left({ }^{\circ} \mathrm{C}\right)\end{array}$} & \multirow[t]{3}{*}{ Source } & \multirow[t]{3}{*}{$\mathrm{n}$} & \multicolumn{4}{|c|}{$\longrightarrow$ Pool C } & \multicolumn{4}{|c|}{$\longrightarrow$ Pool B } & \multicolumn{4}{|c|}{$\longrightarrow$ Pool A } \\
\hline & & & & \multicolumn{2}{|c|}{ Size (\%) } & \multicolumn{2}{|c|}{$k_{\mathrm{e}}\left(\% \mathrm{~d}^{-1}\right)$} & \multicolumn{2}{|c|}{ Size (\%) } & \multicolumn{2}{|c|}{$k_{\mathrm{e}}\left(\% \mathrm{~d}^{-1}\right)$} & \multicolumn{2}{|c|}{ Size $(\%)$} & \multicolumn{2}{|c|}{$k_{\mathrm{e}}\left(\% \mathrm{~d}^{-1}\right)$} \\
\hline & & & & Mean & SE & Mean & SE & Mean & SE & Mean & SE & Mean & SE & Mean & $\mathrm{SE}$ \\
\hline \multirow[t]{4}{*}{$\mathrm{Ag}$} & 2 & Arctic & 4 & & & & & 28.3 & 4.7 & 261 & 29 & 71.7 & 4.7 & 3.31 & 0.37 \\
\hline & 2 & Temperate & 3 & & & & & 61.1 & 1.7 & 259 & 44 & 38.9 & 1.7 & 5.06 & 0.53 \\
\hline & 12 & Arctic & 4 & & & & & 14.1 & 1.9 & 373 & 169 & 85.9 & 1.9 & 6.76 & 0.71 \\
\hline & 12 & Temperate & 6 & 38 & 3.2 & 2529 & 170 & 38.7 & 3.8 & 136 & 8 & 23.3 & 1.8 & 4.98 & 0.79 \\
\hline \multirow[t]{4}{*}{$\mathrm{Am}$} & 2 & Arctic & 4 & & & & & 19.9 & 2.4 & 243 & 88 & 80.1 & 2.4 & 2.8 & 0.19 \\
\hline & 2 & Temperate & 3 & & & & & 18.8 & 2.6 & 256 & 36 & 81.2 & 2.6 & 1.14 & 0.14 \\
\hline & 12 & Arctic & 4 & & & & & & & & & 100 & 0 & 2.6 & 0.22 \\
\hline & 12 & Temperate & 6 & & & & & 31.3 & 1.6 & 517 & 73 & 68.7 & 1.6 & 2.98 & 0.26 \\
\hline \multirow[t]{4}{*}{$\mathrm{Cd}$} & 2 & Arctic & 4 & & & & & 24.8 & 2.2 & 516 & 93 & 75.2 & 2.2 & 3.19 & 0.15 \\
\hline & 2 & Temperate & 4 & & & & & 5.8 & 1.3 & 564 & 125 & 94.2 & 1.3 & 0.23 & 0.08 \\
\hline & 12 & Arctic & 4 & & & & & 29.7 & 3.7 & 290 & 60 & 70.3 & 3.7 & 3.98 & 0.38 \\
\hline & 12 & Temperate & 3 & & & & & 18.8 & 4.4 & 150 & 41 & 81.2 & 4.4 & 0.73 & 0.38 \\
\hline \multirow[t]{4}{*}{ Co } & 2 & Arctic & 4 & & & & & 27.3 & 2.3 & 488 & 235 & 72.7 & 2.3 & 2.54 & 0.42 \\
\hline & 2 & Temperate & 3 & & & & & 38.6 & 4.2 & 102 & 13 & 61.4 & 4.2 & 2.93 & 0.31 \\
\hline & 12 & Arctic & 4 & & & & & 14.5 & 1.6 & 178 & 37 & 85.5 & 1.6 & 3.78 & 0.22 \\
\hline & 12 & Temperate & 6 & & & & & 32.8 & 1.7 & 715 & 1.4 & 67.2 & 1.7 & 3.22 & 0.46 \\
\hline \multirow[t]{4}{*}{$\mathrm{Zn}$} & 2 & Arctic & 4 & & & & & 19.6 & 1.3 & 186 & 30 & 80.4 & 1.3 & 4.78 & 0.42 \\
\hline & 2 & Temperate & 4 & & & & & 20.7 & 1.5 & 242 & 33 & 79.3 & 1.5 & 1.14 & 0.35 \\
\hline & 12 & Arctic & 4 & & & & & 26.1 & 5.9 & 77 & 20 & 73.9 & 5.9 & 7.78 & 1.19 \\
\hline & 12 & Temperate & 3 & & & & & 37.7 & 2.2 & 89 & 12 & 62.3 & 2.2 & 3.56 & 0.65 \\
\hline
\end{tabular}


Table 5. Mytilus edulis. ANOVA results for all data on size of internal radiotracer pool with slowest turnover (Pool A from Table 4), and efflux rate constant, $k_{\mathrm{e}}$. Effects are metal, source (for geographic origin of mussels), temperature, $T$ (for experimental temperature) and interactions between these variables. The $\mathrm{r}^{2}$ values for 'Total' are for the model and are adjusted for number of parameters and degrees of freedom; those for individual effects are partial values calculated by dividing effect SS by total SS. Other details as for Table 2

\begin{tabular}{|c|c|c|c|c|c|c|c|c|c|}
\hline \multirow[t]{2}{*}{ Effect } & \multirow[t]{2}{*}{$\mathrm{df}$} & \multicolumn{4}{|c|}{ — Pool A size -} & \multicolumn{4}{|c|}{ Efflux rate constant, $k_{\mathrm{e}}$} \\
\hline & & $\mathrm{r}^{2}$ & SS & F-ratio & p-values & $\mathrm{r}^{2}$ & SS & F-ratio & p-values \\
\hline Total & 61 & 0.92 & 28025 & 47.6 & $<0.0001$ & 0.73 & 0.0328 & 12.6 & $<0.0001$ \\
\hline Metal & 4 & 0.27 & 7470 & 64.3 & $<0.0001$ & 0.31 & 0.0100 & 22.9 & $<0.0001$ \\
\hline Source & 1 & 0.13 & 3684 & 126.9 & $<0.0001$ & 0.14 & 0.0047 & 42.7 & $<0.0001$ \\
\hline Metal $\times$ Source & 4 & 0.28 & 7844 & 67.5 & $<0.0001$ & 0.16 & 0.0051 & 11.6 & $<0.0001$ \\
\hline$T$ & 1 & 0 & 54 & 1.8 & 0.18 & 0.10 & 0.0034 & 31.1 & $<0.0001$ \\
\hline Metal $\times T$ & 4 & 0.04 & 1169 & 10.1 & $<0.0001$ & 0.04 & 0.0012 & 2.6 & 0.042 \\
\hline$T \times$ Source & 1 & 0.05 & 1483 & 51.1 & $<0.0001$ & 0.01 & 0.0002 & 1.9 & 0.17 \\
\hline Metal $\times T \times$ Source & 4 & 0.02 & 607 & 5.2 & $<0.0001$ & 0.05 & 0.0016 & 3.6 & 0.011 \\
\hline
\end{tabular}

effect $(23 \%)$ only on the proportion of Co located in the slowest turnover pool.

Efflux rate constants of absorbed metal from the slowest turnover pool (Table 4) were generally highest for Ag, followed by $\mathrm{Zn}, \mathrm{Co}, \mathrm{Am}$ and $\mathrm{Cd}$, based on leastsquares mean estimates of the ANOVA of all metal data. Differences among the elements were again the most important source of variability in efflux rate constants (Table 5). Population source was also important for $\mathrm{Cd}$ and $\mathrm{Zn}$ for which loss rates were 6.5 and 1.7 times slower in temperate mussels than in Arctic mussels. There was almost no effect of population source on the efflux rates of the other elements. Temperature also had a significant effect on efflux rates, accounting for $10 \%$ of the variance (Table 5). Efflux rates were consistently 20 to $50 \%$ slower at $2^{\circ} \mathrm{C}$ than at $12^{\circ} \mathrm{C}$, although the difference was only significant in 2 of the metal-specific ANOVAs due to the relatively low statistical power in those analyses (Table 6).

The distribution of radiolabel between shell and soft tissues differed among the metals but did not vary with time during the exposure period (Fig. 4). Nearly $90 \%$ of the Ag was associated with soft tissues during the exposure phase, whereas the other metals ranged from 50 to $60 \%$ in the soft tissues. The distribution of metal between shell and soft tissues changed over the course of depuration in the temperate mussels at $12^{\circ} \mathrm{C}$ (Fig. 4). The fraction of Ag in soft tissues declined from $70 \%$ after $0.5 \mathrm{~d}$ to about $30 \%$ after $12 \mathrm{~d}$ of depuration. Over the same period the fraction of Am and Co in soft tissues also declined, but less steeply, from 40 and $25 \%$, respectively, to $15 \%$. In contrast, the proportion of $\mathrm{Zn}$ increased from 60 to $80 \%$ and the fraction of $\mathrm{Cd}$ in soft tissues from 67 to about $95 \%$. For most of the metals, the final fraction of radiolabel in soft tissues at the end of an $8 \mathrm{~d}$ depuration was higher at $2^{\circ} \mathrm{C}$ than at $12^{\circ} \mathrm{C}$ (Fig. 5), but Am showed no such effect. Ag (50 to $25 \%$ ) and Zn (65 to $40 \%$ ) exhibited the largest differences in absolute terms, while $\mathrm{Cd}(90$ to $80 \%$ ) and $\mathrm{Co}$ (20 to $10 \%$ ) exhibited more modest differences.

The $\mathrm{CF}_{\mathrm{w}}$ values for each metal varied relatively little on average for any mussel population (Fig. 6). This

Table 6. Mytilus edulis. Results of metal-specific ANOVAs on size of slowest turnover internal pool of metal and efflux constant. Further details as for Table 3

\begin{tabular}{|c|c|c|c|c|c|c|c|c|c|c|}
\hline \multirow[t]{2}{*}{ Element } & \multicolumn{2}{|c|}{ Whole model } & \multicolumn{3}{|c|}{ — Population source $\_$} & \multicolumn{3}{|c|}{ — Temperature $\_$} & \multicolumn{2}{|c|}{ Interaction } \\
\hline & $\mathrm{r}^{2}$ & $\mathrm{p}$ & Effect & Partial & $\mathrm{p}$ & Effect & Partial & $\mathrm{p}$ & Partial & $\mathrm{p}$ \\
\hline \multicolumn{11}{|l|}{ Pool size } \\
\hline $\mathrm{Ag}$ & 95.6 & $<0.0001$ & 153 & 75.7 & $<0.0001$ & 1 & 0.0 & 0.82 & 7.3 & 0.0002 \\
\hline $\mathrm{Am}$ & 90.8 & $<0.0001$ & 20 & 35.9 & $<0.0001$ & -4 & 2.2 & 0.48 & 41.2 & $<0.0001$ \\
\hline $\mathrm{Cd}$ & 71.8 & 0.0006 & -17 & 50.3 & 0.0004 & 12 & 18.0 & 0.012 & 3.6 & 0.21 \\
\hline $\mathrm{Co}$ & 76.3 & $<0.0001$ & 23 & 58.6 & $<0.0001$ & -12 & 23.2 & 0.0016 & 3.3 & 0.16 \\
\hline $\mathrm{Zn}$ & 45.9 & 0.02 & 9 & 12.7 & 0.1 & 17 & 0.0 & 0.017 & 8.5 & 0.17 \\
\hline \multicolumn{11}{|c|}{ Efflux rate constant for largest pool } \\
\hline $\mathrm{Ag}$ & 33.7 & 0.04 & 0 & 0.0 & 0.99 & -29 & 22.1 & 0.038 & 24.1 & 0.032 \\
\hline $\mathrm{Am}$ & 63.4 & 0.001 & 31 & 15.6 & 0.02 & -30 & 26.1 & 0.0049 & 39.7 & 0.0011 \\
\hline $\mathrm{Cd}$ & 91.1 & $<0.0001$ & 646 & 85.9 & $<0.0001$ & -28 & 3.7 & 0.034 & 0.2 & 0.59 \\
\hline $\mathrm{Co}$ & 7.7 & 0.28 & 3 & 0.2 & 0.84 & -22 & 18.0 & 0.1 & 7.0 & 0.29 \\
\hline $\mathrm{Zn}$ & 74.1 & 0.0004 & 167 & 49.9 & 0.0003 & -48 & 23.8 & 0.0043 & 0.3 & 0.71 \\
\hline
\end{tabular}



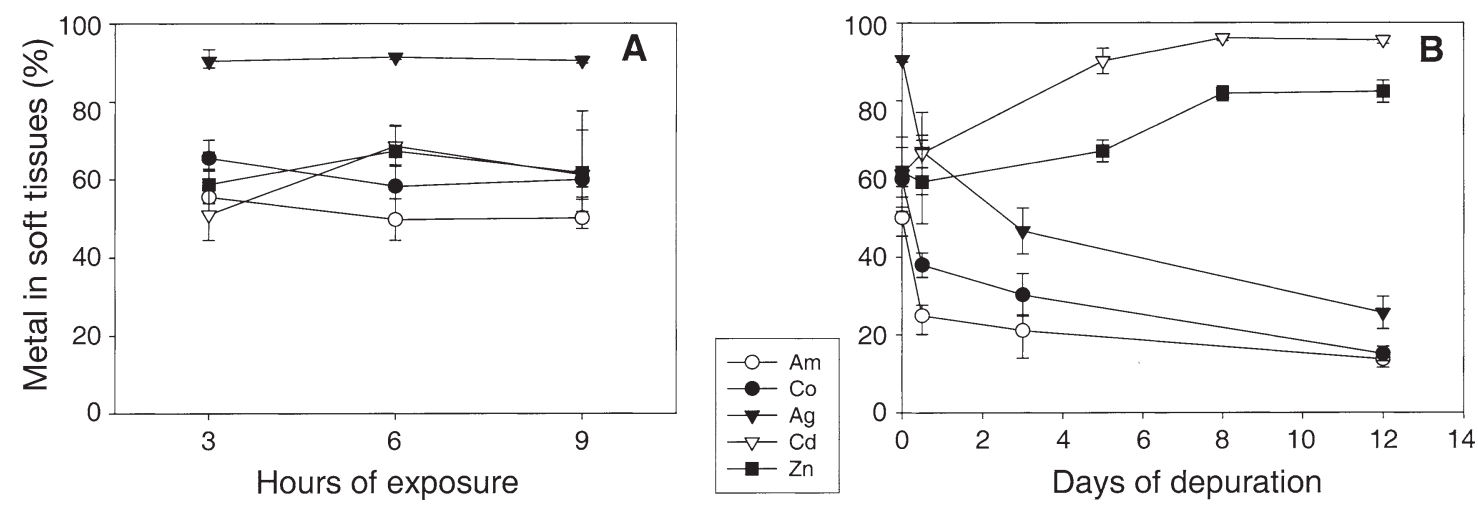

Fig. 4. Mytilus edulis. Time series of distribution of metal between soft tissues and shell during (A) radioactive exposure period and (B) depuration period in temperate mussels at $12^{\circ} \mathrm{C}$. Initial time points in (B) are final time points at $9 \mathrm{~h}$ in (A). Data points are means \pm SE for different sets of 3 to 4 individuals. Mussels were collected in November 2003

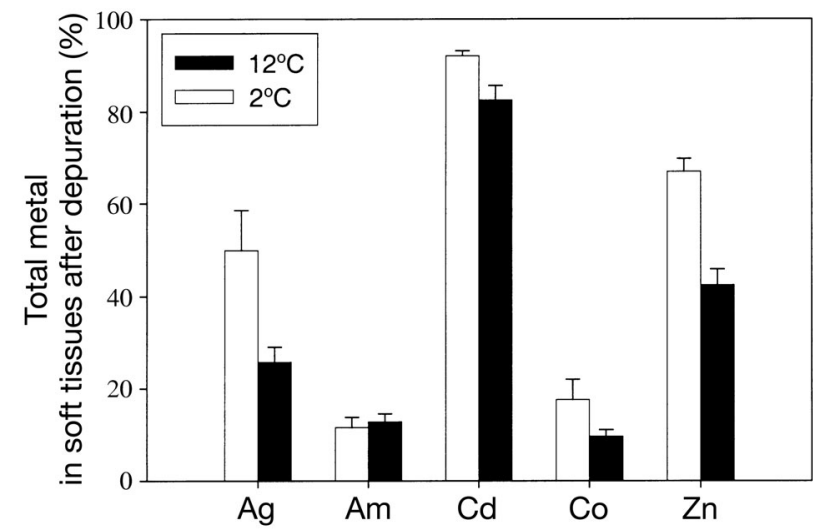

Fig. 5. Mytilus edulis. Percent total body burden of metal in soft tissue at end of $8 \mathrm{~d}$ depuration for temperate mussels at 2 and $12^{\circ} \mathrm{C}$. Data points are means + SE for 5 individuals. Mussels were collected in March 2003

reflects the fact that uptake from the dissolved phase and efflux from the mussel were correlated, with Ag and $\mathrm{Zn}$ displaying high uptake and efflux, while Am and $\mathrm{Cd}$ exhibited relatively low uptake and efflux. Temperature had no discernible effect on $\mathrm{CF}_{\mathrm{w}}$ values; slightly higher uptake at higher temperatures was almost exactly balanced by faster losses. However, for 2 metals there were large differences among the 2 populations: $\mathrm{Cd}$ and $\mathrm{Zn}$ were 15- and 2.6-fold more efficiently accumulated by temperate mussels than by Arctic mussels (Fig. 6).

\section{DISCUSSION}

The relative magnitudes of the uptake rate constants for various metals presented here were similar to those previously observed (Wang et al. 1996). Ag was taken up most efficiently, possibly because of its tendency in

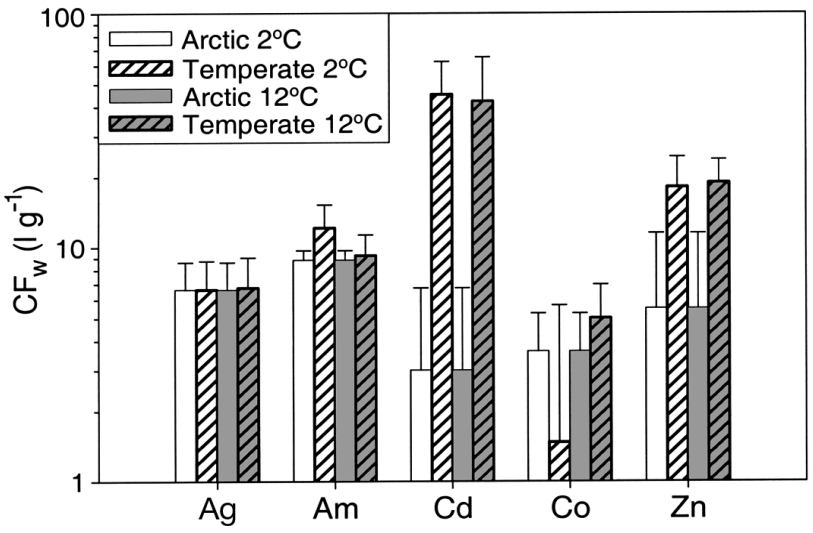

Fig. 6. Mytilus edulis. Mean (+SE) concentration factor from water. $\mathrm{CF}_{\mathrm{w}}$ values (calculated as $k_{\mathrm{u}} / k_{\mathrm{e}}$, where $k_{\mathrm{u}}=$ uptake rate constant and $k_{\mathrm{e}}=$ efflux rate constant) are for 5 metals in Arctic and temperate mussels at 2 and $12{ }^{\circ} \mathrm{C}$

seawater to form chloro-complexes that may cross membranes (Reinfelder et al. 1998). As in past studies, $\mathrm{Zn}$, a metal that has many biological uses within organisms, was taken up next fastest, while Am and $\mathrm{Cd}$ were taken up at intermediate rates and Co at the slowest rate. The absolute values for uptake rates of all metals in temperate Mytilus edulis at $12^{\circ} \mathrm{C}$ were generally comparable with earlier findings for temperate M. edulis studied at $15^{\circ} \mathrm{C}$ (Table 7), but absorption efficiencies were lower in this study than previous findings (Table 7). These differences are probably attributable to differences in filtration rates between the different studies. Differences in the distribution of $\mathrm{Zn}$ in the soft parts of mussels from different experiments on metal distribution (Figs. $4 \& 5$ ) may be due to the different physiological states of the mussels (fall vs. spring collections). For example, the mussels in the experiments depicted in Fig. 5 may have been building-up reproductive tissues in preparation for the late- 
Table 7. Mytilus spp. Comparison of mean uptake rates $\left(k_{\mathrm{u}}, \mathrm{lg}^{-1} \mathrm{~d}^{-1}\right)$, absorption efficiencies (AbE, \%), distribution in mussel soft parts at onset of depuration (\% s.p.), and efflux rates $\left(k_{\mathrm{e}}, \% \mathrm{~d}^{-1}\right)$ of metals in mussel soft parts following absorption from dissolved phase reported in 4 studies; only mussels from temperate waters are compared. Efflux rates are from slowest exchanging pools in soft parts. -: not determined

\begin{tabular}{|c|c|c|c|c|c|c|c|c|c|c|c|c|c|c|c|c|}
\hline \multirow[t]{2}{*}{ Metal } & \multicolumn{4}{|c|}{ Present study, $12^{\circ} \mathrm{C}$} & \multicolumn{4}{|c|}{ Fisher et al. (1996), $15^{\circ} \mathrm{C}^{\mathrm{a}}$} & \multicolumn{4}{|c|}{ Wang et al. (1996), $15^{\circ} \mathrm{C}^{\mathrm{b}}$} & \multicolumn{4}{|c|}{ Wang \& Fisher $(1997), 15^{\circ} \mathrm{C}^{\mathrm{C}}$} \\
\hline & $k_{\mathrm{u}}$ & $\mathrm{AbE}$ & $\%$ s.p. & $k_{\mathrm{e}}$ & $k_{\mathrm{u}}$ & $\mathrm{AbE}$ & $\%$ s.p. & $k_{\mathrm{e}}$ & $k_{\mathrm{u}}$ & $\mathrm{AbE}$ & $\%$ s.p. & $k_{\mathrm{e}}$ & $k_{\mathrm{u}}$ & $\mathrm{AbE}$ & $\%$ s.p. & $k_{\mathrm{e}}$ \\
\hline $\mathrm{Ag}$ & 1.44 & 0.35 & 68 & 4.98 & - & - & 55 & 4.72 & 1.79 & 1.53 & - & 1.5 & - & - & - & - \\
\hline $\mathrm{Am}$ & 0.40 & 0.17 & 25 & 2.98 & - & - & 34 & 3.21 & 0.40 & 0.34 & - & 2.3 & - & - & - & - \\
\hline $\mathrm{Cd}$ & 0.38 & 0.12 & 68 & 0.73 & - & - & 56 & 1.81 & 0.37 & 0.31 & - & 2.1 & 0.58 & 0.18 & - & 3.24 \\
\hline Co & 0.24 & 0.08 & 40 & 3.22 & - & - & 51 & 4.10 & 0.12 & 0.11 & - & 2.3 & 0.15 & 0.05 & - & 3.26 \\
\hline $\mathrm{Zn}$ & 1.08 & 0.33 & 60 & 3.56 & - & - & 38 & 2.05 & 1.04 & 0.89 & - & 1.5 & 1.46 & 0.47 & - & 1.41 \\
\hline
\end{tabular}

spring spawning, whereas the mussels in the experiments in Fig. 4 were probably not doing so. However, the distributions of other metals were generally comparable between the experiments. The physiological turnover of both Ag and $\mathrm{Zn}$ (but not Am) in mussels has been shown to vary with season, indicating that spawning and other processes can affect retention of these protein-associated metals (Dahlgaard 1986).

Recycling and reduction of filtration rates over time during exposure to particle-free water during long radiolabeling periods may lead to an underestimation of metal uptake rates from the dissolved phase. However, we found that uptake was generally linear over a $12 \mathrm{~h}$ period for all metals except $\mathrm{Ag}$ at $12^{\circ} \mathrm{C}$. A decline in pumping rate by the mussels could not have caused the non-linearity seen in Ag, since no other metal showed this trend in mussels that were exposed to other isotopes simultaneously with Ag.

Variability in rates of metal uptake from the dissolved phase at different temperatures and, to a lesser degree, for different populations, is primarily a function of mussel filtration rate. Average uptake rates for metals at $12^{\circ} \mathrm{C}$ were at most $50 \%$ larger than uptake at $2^{\circ} \mathrm{C}$. As expected for properly acclimated mussels (Widdows 1973, Bayne \& Newell 1983, Jørgensen 1990) filtration rates were also about $50 \%$ higher at $12^{\circ} \mathrm{C}$ than at $2^{\circ} \mathrm{C}$. As a consequence, there was no effect of temperature on absorption efficiencies because the uptake rate constants and filtration rates almost exactly cancelled each other. This poses the possibility that successful modeling of metal uptake from the dissolved phase at different temperatures requires mainly that the response of filtration rates to temperature be understood. Once variability in filtration rate is understood, uptake rates can be estimated using the metal-specific absorption efficiencies that are fairly stable across diverse experimental conditions.
Modeling of the depuration parameters indicated that there was a large fraction (61 to $77 \%$ ) of ${ }^{110 \mathrm{~m}} \mathrm{Ag}$ taken up into internal pools that turned over more than once per day in temperate mussels. The other metals typically displayed lower body burdens in these rapidly exchanging pools (Table 4). Wang et al. (1996) similarly observed that $82 \%$ of the Ag taken up by temperate $M$. edulis over a $12 \mathrm{~h}$ period at $15^{\circ} \mathrm{C}$ was deposited in rapidly exchanging pools, significantly higher than for other metals in their study. Metal efflux rates from the slowest exchanging pools in the soft parts of the temperate $M$. edulis measured herein are compared with those found in earlier studies in Table 7. Generally, the efflux rates obtained herein for temperate mussels at $12^{\circ} \mathrm{C}$ were comparable to results of Fisher et al. (1996). Note that, with the notable exception of $\mathrm{Cd}$, the efflux rates from soft parts that we observed were higher than from whole mussels observed previously (Table 7); this difference is due to the fact that metals that are accumulated from the dissolved phase are typically retained more effectively by shells than by soft parts (Fisher et al. 1996).

As long as filtration rates stay constant, use of longer labeling periods may actually be preferable to use of short-term labeling. The longer period of exposure to radiolabel may allow better labeling of the slowly exchanging pool (with slower turnover) and better estimation of uptake into this pool without the interference of the faster turnover pools. Successfully estimating flow into the slowly exchanging pool is important because it is likely to comprise the largest fraction of metal taken in from the dissolved phase in mussels. The size of this fraction is apparent from the depuration results in Table 4. The depuration curves for Am, $\mathrm{Cd}$, Co and $\mathrm{Zn}$ imply that $>60 \%$ of the radiolabel is in the slow turnover pool. The actual fraction of metal in the slowest exchanging pool was probably much 
larger. The amount of radiolabel in the slowest exchanging pool, $R^{\prime}$, at equilibrium when efflux, $E$, is equal to uptake, $U$, can be estimated by rearranging the equation $U=E=k_{\mathrm{e}} \times R^{\prime}$. Because the maximum turnover rate of radiolabel in the slowest exchanging pool was $\sim 8 \% \mathrm{~d}^{-1}$ (for $\mathrm{Zn}$ in the Arctic mussels at $12^{\circ} \mathrm{C}$ ), $R^{\prime}$ is predicted to be 12.5 times the amount of radiolabel taken up daily. Thus, for every isotope we tested, the amount of radiolabel taken up into the slowest exchanging compartment over $0.5 \mathrm{~d}$ of exposure amounts to only $1 / 25$ th or $4 \%$ of the expected pool size at equilibrium.

Both influx and efflux of metals into/out of mussels was temperature-dependent, suggesting that metabolic rates directly influence these processes by affecting pumping rates and metabolic turnover of metal absorbed in mussel tissue. This is consistent with the observations of Wang \& Fisher (1997), who showed that these rates, normalized to the weights of Mytilus edulis, were inversely related to the size of individual mussels; i.e. smaller mussels with higher weightspecific metabolic rates displayed higher metal uptake and turnover rates. The increase in the uptake rate constant with increasing temperature that we observed was offset by equivalent increases in the efflux of metal from the mussels. As a consequence, the net accumulation of metal from the dissolved phase was not related to temperature. This contrasts markedly with the effect of temperature on bioaccumulation of metal from food (Baines et al. 2005). The assimilation efficiency of metal from food at $2^{\circ} \mathrm{C}$ is significantly higher, and the efflux rate constant for loss from the body is lower. Even though the filtration and ingestion rates are slower at $2^{\circ} \mathrm{C}$ that at $12^{\circ} \mathrm{C}$, the trophic accumulation factor ranged from about 2 -fold higher at $2^{\circ} \mathrm{C}$ for $\mathrm{Zn}$ to about 9-fold higher for Ag (Baines et al. 2005). Thus, at lower temperatures food becomes relatively more important as a pathway for the introduction of metals into $M$. edulis, and the dissolved phase becomes less important, particularly for Ag and Am. Such a shift in importance of the pathways of metal transport into mussels could significantly alter predicted relationships between suspended solid concentrations and contaminant loads (Wang et al. 1996).

The ability to bioconcentrate dissolved $\mathrm{Cd}$ and $\mathrm{Zn}$ differed markedly between the Arctic and the temperate mussels, regardless of temperature, and this was primarily due to large differences in efflux rates for these metals. The cause of this difference between populations is unknown, and it is not clear whether this represents the symptom of some broad adaptation to life in temperate as opposed to Arctic regions. The high retention of metals in temperate mussels could relate to either a disproportional abundance of binding agents, such as metallothioneins, or a propensity to deposit the metal in insoluble form within tissues (George 1990, Mason \& Jenkins 1995) in the temperate mussels, although these were not directly measured in our experiments. In any case, it is apparent from the $\mathrm{Cd}$ and $\mathrm{Zn}$ data that the tissue concentrations of these metals in temperate mussels may not be appropriate for understanding patterns of contamination in Arctic mussels.

Acknowledgements. We thank S. E. Hook, S. Palma, G. S. Stewart, and P. K. Lam for laboratory assistance, and L. Føyn for providing mussels from Norway. This research was supported by the US National Science Foundation (OPP9986069). This is Contribution Number 1293 of the Marine Sciences Research Center.

\section{LITERATURE CITED}

Baines SB, Fisher NS, Stewart R (2002) Assimilation and retention of selenium and other trace elements from crustacean food by juvenile striped bass (Morone saxatilis). Limnol Oceanogr 47:646-655

Baines SB, Fisher NS, Kinney EL (2005) The influence of temperature on dietary metal uptake in Arctic and temperate mussels. Mar Ecol Prog Ser 289:201-213

Bayne BL, Newell RC (1983) Physiological energetic of marine molluscs. In: Aleudin ASM, Wilber KM (eds) The Mollusca. Vol 4. Physiology. Academic Press, New York, p 407-515

Dahlgaard H (1986) Effects of season and temperature on long-term in situ loss rates of $\mathrm{Pu}, \mathrm{Am}, \mathrm{Np}, \mathrm{Eu}, \mathrm{Ce}, \mathrm{Ag}$, Tc, Zn, Co and Mn in a Baltic Mytilus edulis population. Mar Ecol Prog Ser 33:157-165

Dietz R, Pacyna J, Thomas DJ (1998) Heavy metals. In: AMAP Assessment report: Arctic pollution issues. Arctic monitoring and assessment programme (AMAP), Oslo, p 373-524

Fisher NS (1986) On the reactivity of metals for marine phytoplankton. Limnol Oceanogr 31:443-449

Fisher NS (2002) Advantages and problems in the application of radiotracers for determining the bioaccumulation of contaminants in aquatic organisms. In: Borretzen P, Jolle T, Strand P (eds) Proc Int Conf Radioactivity in the Environment, 1-5 Sep 2002, Monaco. Norwegian Radiation Protection Authority, Østerås, p 573-576

Fisher NS, Reinfelder JR (1995) The trophic transfer of metals in marine systems. In: Tessier A, Turner DR (eds) Metal speciation and bioavailability in aquatic systems. John Wiley \& Sons, Chichester, p 363-406

Fisher NS, Teyssié JL, Fowler SW, Wang WX (1996) Accumulation and retention of metals in mussels from food and water: a comparison under field and laboratory conditions. Environ Sci Technol 30:3232-3242

Fisher NS, Fowler SW, Boisson F, Carroll JL, Rissanen K, Salbu B, Sazykina TG, Sjoeblom KL (1999) Radionuclide bioconcentration factors and sediment partition coefficients in Arctic seas subject to contamination from dumped nuclear wastes. Environ Sci Technol 33: 1979-1982

Fisher NS, Stupakoff I, Sañudo-Wilhelmy S, Wang WX, Teyssié JL, Fowler SW, Crusius J (2000) Trace metals in marine copepods: a field test of a bioaccumulation model coupled to laboratory uptake kinetics data. Mar Ecol Prog Ser 194:211-218

George SG (1990) Biochemical and cytological assessments of 
metal toxicity in marine animals. In: Furness RW, Rainbow PS (eds) Heavy metals in the marine environment. CRC Press, Boca Raton, FL, p 123-142

Griscom SB, Fisher NS (2002) Uptake of dissolved Ag, Cd, and Co by the clam, Macoma balthica: relative importance of overlying water, oxic pore water and burrow water. Environ Sci Technol 36:2471-2478

Hansen JC (1998) Pollution and human health. In: AMAP assessment report: Arctic pollution issues. Arctic monitoring and assessment programme (AMAP), Oslo, p 775-844

Hutchins DA, Stupakoff I, Fisher NS (1996) Temperature effects on accumulation and retention of radionuclides in the sea star, Asterias forbesi: implications for contaminated northern waters. Mar Biol 125:701-706

Hutchins DA, Stupakoff I, Hook S, Luoma SN, Fisher NS (1998) Effects of Arctic temperatures on distribution and retention of the nuclear waste radionuclides ${ }^{241} \mathrm{Am},{ }^{57} \mathrm{Co}$, and ${ }^{137} \mathrm{Cs}$ in the bioindicator bivalve Macoma balthica. Mar Environ Res 45:17-28

Jørgensen CB (1990) Bivalve filter feeding: hydrodynamics, bioenergetics, physiology and ecology. Olsen \& Olsen, Fredensborg

Mason AZ, Jenkins KD (1995) Metal detoxification in aquatic organisms. In: Tessier A, Turner DR (eds) Metal speciation and bioavailability in aquatic systems. John Wiley \& Sons, Chichester, p 479-608

Nieboer E, Richardson DH (1980) The replacement of the nondescript term 'heavy metals' by a biological and chemically significant classification of metal ions. Environ Pollut Ser B 1:3-26

Phillips DJH (1980) Quantitative aquatic biological indicators. Applied Science Publishers, London

Reinfelder JR, Fisher NS, Luoma SN, Nichols JW, Wang WX

Editorial responsibility: Otto Kinne (Editor-in-Chief),

Oldendorf/Luhe, Germany
(1998) Trace element trophic transfer in aquatic organisms: a critique of the kinetic model approach. Sci Total Environ 219:117-135

Riginos C, Sukhdeo K, Cunningham CW (2002) Evidence for selection at multiple allozyme loci across a mussel hybrid zone. Mol Biol Evol 19:347-351

Roditi HA, Fisher NS, Sañudo-Wilhelmy SA (2000) Field testing a metal bioaccumulation model for zebra mussels. Environ Sci Technol 34:2817-2825

Strand P (1998) Radioactivity. In: AMAP Assessment report: Arctic pollution issues. Arctic monitoring and assessment programme (AMAP), Oslo, p 525-620

Templeton W, Harrison F, Knezovich J, Fisher N, and Layton D (1997) Bioconcentration of radionuclides in marine foodweb organisms. In: Layton D, Edson R, Varela M, Napier B (eds) Radionuclides in the Arctic seas from the former Soviet Union: potential health and ecological risks. Office of Naval Research, Washington, DC, 4-1-4-12

Wang WX, Fisher NS (1997) Modeling the influence of body size on trace element accumulation in the mussel Mytilus edulis. Mar Ecol Prog Ser 161:103-115

Wang WX, Fisher NS (1999) Delineating metal accumulation pathways for aquatic invertebrates. Sci Total Environ 237/238:459-472

Wang WX, Fisher NS, Luoma SN (1995) Assimilation of trace elements ingested by the mussel Mytilus edulis: effects of algal food abundance. Mar Ecol Prog Ser 129:165-176

Wang WX, Fisher NS, Luoma SN (1996) Kinetic determinations of trace element bioaccumulation in the mussel Mytilus edulis. Mar Ecol Prog Ser 140:91-113

Widdows J (1973) Effect of temperature and food on heart beat, ventilation rate and oxygen-uptake of Mytilus edulis. Mar Biol 20:269-276

Submitted: November 4, 2004; Accepted: June 25, 2005

Proofs received from author(s): November 21, 2005 